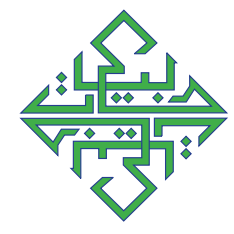

\title{
TANTANGAN GURU BAHASA ARAB MADRASAH ALIYAH DALAM PERSPEKTIF KOMPETENSI PEDAGOGIK DAN PROFESIONAL
}

\author{
Maman Abdurrahman, A. Suherman, Masor, Asep M. Irfan Fadhlillah \\ Sekolah Pascasarjana Universitas Pendidikan Indonesia \\ e-mail : mamanabdurrahman@upi.edu
}

Naskah diterima: 22 Februari 2015, direvisi: 25 Maret 2015, disetujui: 28 April 2015.

\begin{abstract}
Pedagogic \& professional competence at the teacher is needed in the teaching \& learning Arabic. Therefore it is needed a good preparation to support bath at competences in the teaching \& learning Arabic. objectives of this study is to describe the important role of pedagogic and professional competence of Arabic teachers in Bandung, and their efforts to enhance both competences. The method used in this research is Naturalist Inquiry, by using Pedoman Penilaian Kinerja Guru Kemendiknas tahun 2010 for forty five Arabic teachers in Bandung. The result of the study showed that the degree of professional \& pedagogic competence of Arabic teachers are normal (C). A caused by the linearity of their education. To be a Muallim Najih fi al-lughah Al-Arabiyah it needed a good professional and pedagogic competence.
\end{abstract}

Keywords : Arabic teacher, pedagogic competence, professional competence

\section{Abstrak}

Kompetensi Profesional dan pedagogik pendidik sangat dibutuhkan dalam proses pembelajaran bahasa Arab. Karena itu dibutuhkan persiapan yang menunjang lahirnya dua kompetensi tersebut dalam proses pembelajaran bahasa Arab. Tujuan penelitian ini adalah mendeskripsikan tentang pentingnya kompetensi pedagogik dan profesional guru bahasa Arab di kota Bandung serta upayaupaya yang dilakukan untuk meningkatkan kompetensi tersebut. Metode yang digunakan pada penelitian ini adalah Naturalistik inquiry dengan menggunakan Pedoman Penilaian Kinerja Guru Kemendiknas tahun 2010 terhadap 44 guru Bahasa Arab di Bandung. Hasil penelitian menunjukan bahwa tingkat kompetensi pedagogik dan profesional guru bahasa Arab mendapatkan nilai $\mathrm{C}$ atau cukup. Salah satu penyebabnya adalah linearitas pendidikan untuk menjadi Muallim Najih fil allughah Al-Arabiyah diperoleh kompetensi pedagogik dan profesional yang baik.

Kata Kunci : guru bahasa Arab, kompetensi pedagogik, kompetensi profesional

How to Cite : Abdurrahman, Maman., dkk. "TANTANGAN GURU BAHASA ARAB MADRASAH ALIYAH DALAM PERSPEKTIF KOMPETENSI PEDAGOGIK DAN PROFESIONAL" ARABIYAT : Jurnal Pendidikan Bahasa Arab dan Kebahasaaraban [Online], Volume 2 Number 1 (30 Juni 2015)

Permalink/DOI: $h$ ttp://dx.doi.org/10.15408/a.v2i1.1513 


\section{Pendahuluan}

Menurut Arifin, guru merupakan salah satu komponen dari enam komponen utama yang merupakan faktor penentu keterlaksanaan dan suksesnya program pendidikan, yaitu: 1) guru, 2) siswa, 3) materi/kurikulum, 4) sarana dan prasarana, 5) manajemen atau pengelolaan, dan 6) lingkungan ${ }^{1}$. Selanjutnya Sauri menjelaskan guru profesional merupakan sosok sumber daya insani yang dapat menjadi "nakhoda" agar peran sekolah dan masyarakat dapat berjalan sebagaimana yang diharapkan ${ }^{2}$. Profesionalisme guru yang perlu dibangun oleh Lembaga Pendidikan Tenaga Kependidikan (LPTK) adalah guru yang memiliki kompetensi pedagogik, kompetensi profesional, kompetensi sosial, dan kompetensi kepribadian. Hal ini sesuai dengan Undang-Undang No. 14 tahun 2005 tentang Guru dan Dosen, PP No 74 tahun 2008 tentang guru pasal 3 ayat 2 serta Permendiknas No 16 tahun 2007.

Oleh karena itu, seorang guru bahasa Arab harus menjadi agen perubahan dalam pembelajaran bahasa Arab itu sendiri dan harus mampu menyelenggarakan proses pembelajaran dengan sebaik-baiknya dalam rangka pembangunan pendidikan. Untuk dapat melaksanakan fungsinya dengan baik, guru bahasa Arab wajib memiliki syarat tertentu. Di antaranya adalah kompetensi, terutama kompetensi yang berhubungan langsung dengan kegiatan

\footnotetext{
1 Lihat Zainal Arifin, Penerapan Kompetensi Pedagogik Dan Kompetensi Profesional di Kalangan Guru Bahasa Arab pada Madrasah Tsanawiyah SeKabupaten Rembang (Studi Deskriptif Evaluatif), Tesis Pascasarjana Pendidikan Bahasa Arab Malang: Tidak Diterbitkan, h. 1.

2 Baca Sofyan Sauri, Membangun Profesionalisme Guru Berbasis Nilai Bahasa Santun, Bagi Pembinaan Kepribadian Bangsa yang Bijak, Pengukuhan Guru Besar Universitas Pendidikan Indonesia, (Bandung: UPI Pres, 2006), h. 3.
}

pembelajaran, yaitu kompetensi pedagogik dan kompetensi profesional. Di samping itu, pada prinsipnya kompetensi guru bahasa Arab perlu dibuktikan dengan penerapannya di lapangan, sehingga pernyataan tentang telah atau belum dikuasainya kompetensi tertentu harusdiujidenganhasilpengamatan kegiatan guru dalam pembelajaran bahasa Arab.

Secara naluriah minat belajar siswa terhadap bahasa Arab ada dua faktor yaitu faktor internal dan faktor eksternal. Faktor internal adalah tumbuh dari keinginan sendiri yang medorong terhadap keinginan mempelajari bahasa Arab, bisa dipengaruhi oleh kemampuan sebelumnya yang telah ia kuasai. Dan yang kedua adalah faktor eksternal faktor ini adalah dorongan dari luar sehingga dapat mempengaruhi siswa sehingga siswa berkeinginan utntuk mempelajari bahasa Arab, dalam faktor ini guru bahasa Arab lah yang harus berperan serta mengembangkannya. Jangan serta merta acuh tak acuh dan tidak peka terhadap kedua faktor ini, guru bahasa Arab harus tanggap dan peka terhadap perkembangan peserta didiknya.

Selain harus peka, seorang guru juga haruslah tahan banting terhadap keadaan yang terjadi, misalnya di setiap ada kasus atau pun peristiwa yang berkaitan dengan siswa, seperti tawuran antarsiswa, perbuatan pornografi, narkoba, pacaran di luar nikah, atau banyaknya siswa yang tidak lulus UN, dan sebagainya, gurulah yang selalu disalahkan serta kerap kali menerima sasaran kritik pedas dari berbagai kalangan dan dianggap sebagai pihak yang paling bertanggung jawab atasakibatdarirendahnyakualitaspendidikan. Sebenarnya, anggapan demikian tidak sepenuhnya benar dan tidak pula sepenuhnya salah, karena jelas guru bukanlah satusatunya faktor yang berperan dalam proses 
pendidikan banyak faktor-faktor lain juga yang ikut serta mengembangkan pendidikan. Akan tetapi, walaupun begitu kritik terhadap guru itu juga jangan sampai ditolak mentahmentah lantas lari dari tanggung jawab. Namun, alangkah lebih bijak dipahami dulu sebagian harapan-harapan masyarakat agar guru terus menerus dapat meningkatkan kualitasnya baik dari segi kompetensi pedagogik dan kompetensi profesionalisme. Dengan terus menerus meningkatkan kualitas dirinya, baik dalam hal kepakaran maupun kepribadiannya, diharapkan guru akan lebih banyakmemberikankontribusibagiperbaikan kualitas penyelenggaraan pendidikan, sorang guru jangan sampai terpancing oleh suasana namun membalas dengan karya adalah sebuah tindakan yang bijak.

Pada kenyataannya, sebagaimana yang telah disinggung diatas tidak sedikit guru yang mengajar bidang studi yang bukan ahlinya atau tidak sesuai dengan disiplin ilmu yang diterima di bangku kuliah. Penulis simpulkan kejadian ini merupakan sebuah pelanggaran amanah yang tidak bisa ditoleransi lagi berlandaskan pada sabda Nabi Muhammad SAW dalam Shahih al-Bukhari ${ }^{3}$ sbb.

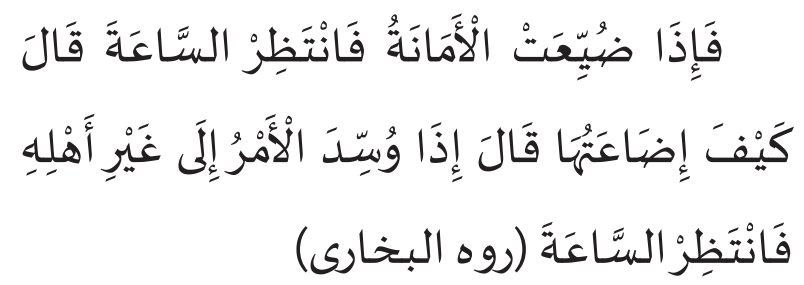

Jika amanah disepelekan, maka tunggulah saat kehancurannya. Shahabat bertanya: apa yang dimaksud menyepelekan amanah? Rasul bersabda: jika urusan diserahkan kepada bukan ahlinya, maka tunggulah saat kehancurannya. (HR. al-Bukhari).

3 Lihat Abu Abdullah Muhammad bin Ismail bin Ibrahim bin al-Mughirah bin Bardizbah al-Ju'fi alBukhari, Shahih al-Bukhariy al-Juz al-Awwal, (Beirut: Dar al-Kutub, tt.), h. 33
Dari hadis di atas penulis menyeru agar pendidikan di negara ini tidak hancur, maka kembalilah wahai guru-guru yang melanggar kode etik amanah ke jalan yang telah diamanahkan oleh pendidikan yang masing-masing diperoleh.

Ternyata persoalan keguruan ini tidak hanya pada ketidaksesuaian latar belakang pendidikan saja, namun ada masalah lain yang mengintai dan mungkin lebih parah dan lebih akut masalahnya yaitu banyak guru yang mampu menguasai materi pelajaran, namun selalu terbentur dalam menyajikan materi tersebut. Hal ini yang membedakan manayangahlual-lughah dan mana yang mudarrisu al-lughah. Seorang ahlu al-lughah merupakan orang yang ahli terhadap bahasa Arab baik dari segi qawaid ataupun sastranya, sedangkan mudarris al-lughah adalah orang yang mengerti dan mampu terhadap bahasa Arab namun juga terampil mengajarkannya. Kenyataan ini sudah menjadi rahasia umum lagi di lembaga-lembaga pendidikan, terutama di sebagian lembaga pendidikan swasta.

Haltersebutbukanberartigurutersebut menjadi tidak profesional, melainkan menjadi 'ragu' dengan profesionalitas pada bidang studi yang bukan profesinya. Hal ini tentunya merupakan sebuah penyimpangan yang legal, apalagi biasanya penyimpangan ini terjadi pada guru yang baru-baru ditempatkan, "yang penting masuk dan ngajar dulu saja masalah profesionalitas belakangan, nanti juga bisa sendiri" ungkap salah seorang guru negeri di salah satu SDN di kabupaten Subang. Hal seperti ini yang justru dikuawatirkan oleh al-Fauzan ${ }^{4}$ :

4 Baca Abdurrahman bin Ibrahim al-Fauzan, Iḍâ̂t li Muallimi al-Lughah al-Arabiyah lighairi alNatiqîn bihâ, (Riyadh: Syirkah al-Arabiyah li al-Jami', 1432 H), h. 260 


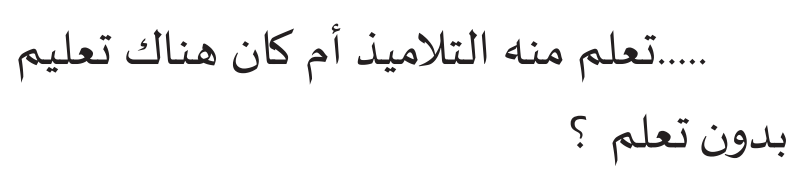

Dhamir /hu/ di sini menunjukan kepada mudarris atau pengajar bahasa Arab Fauzan mengkhawatirkan terjadinya proses pembelajaran yang dilakukan oleh guru bahasa Arab dengan tanpa belajar terlebih dahulu, atau belajar di kelas. Ada juga pribahasa yang jika disalahartikan implikasinya akan mendukung terhadap penyimpangan ini "Mengajar adalah belajar" pribahasa ini hendaknya tidak ditelan mentah-mentah jika ingin belajar maka mengajarlah, jadi belajarnya ketika mengajar, sungguh sebuah statemen yang kurang bijaksana dan menyesatkan.

Penyimpangan profesionalitas menjadi suatu problem besar karena menyangkut pendidikan yang pada dasarnya merupakan wahana pembentuk pribadi dari generasi ke generasi yang akan memikul beban dan tanggungjawab sebagai Khālifah fi alArd. Bekerja sebagai guru atau pendidik bukanlah rutinitas atau kebiasaan yang biasa dilakukan secara "asal-asalan", melainkan suatu bidang yang memerlukan proses perencanaan yang matang serta manajemen yang senantiasa memperhatikan bekerjanya seluruh sistem pembelajaran.

Menciptakan situasi pembelajaran yang baik bukanlah suatu pekerjaan yang mudah seperti membalikan telapak tangan. Karena pembelajaran yang baik sangat membutuhkan keterampilan, latihan-latihan, pengalaman, hal-hal yang berhubungan dengan efektivitas proses pembelajaran, dan harus memiliki keterampilan dalam memilih maupun memilah berbagai macam metode mengajar dan lain sebagainya ${ }^{5}$. Oleh karena itu,

\footnotetext{
5 Abdul Rosyid, Kompetensi Pedagogik Guru Bahasa Arab Berlatar Belakang Non-Pendidikan Bahasa Arab dalam Pembelajaran Bahasa Arab di
}

kompetensi pedagogik dan kompetensi profesional merupakan harga mati yang tidak bisa ditawar lagi bagi seorang guru bahasa Arab.

Sebagaimana yang telah disinggung di atas Sumarsih ${ }^{6}$ (juga mengemukakan bahwa bidang kerja sebagai guru bukanlah pekerjaan yang asal-asalan, melainkan suatu profesi yang memerlukan keahlian. Suatu keahlian tersebut harus diperoleh salah satunya melalui pendidikan formal, karena pendidikan formal memiliki silabus dan kurikulum yang jelas dan ada evaluasi silabus dan kurikulumnya setiap tahun ajaran baru dibanding pendidikan non formal yang tidak jelas arahnya. Dengan demikian, latar belakang pendidikan yang sesuai dengan bidangnya adalah faktor yang tidak dapat diabaikan begitu saja untuk mendukung profesionalitas guru.

Abdul Rosyid kembali mempermasalahkan profesionalitas guru dengan menyuguhkan sebuah pertanyaan "mampukah seorang guru mengajar suatu bidang studi yang bukan disiplin keilmuannya?". Memang, ada guru yang mampu mengajar karena penguasaan materi, tetapi apakah kemampuan tersebut juga disertai dengan kemampuan dalam membentuk kepribadian siswa. Sebab, dalampembentukan kepribadiansiswa,guru secara psikis harus bisa memahami bidang studi yang diampu mulai dari mengerti, memahami, sampai menyikapinya dalam sebuah tindakan pembelajaran di kelas ${ }^{7}$.

Namun pada kenyataannya sebagaimana yang telah penulis ungkapkan di atas sebuah pengakuan dari salah seorang peneliti MTsN Maguwoarjo Yogyakarta. (Yogyakarta: UIN Sunan Kalijaga Yogyakarta, 2013). Skripsi tidak diterbitkan, h. 3

6 Baca Anwar Sumarsih, Kompetensi Guru Madrasah, (Jakarta: Balai Penelitian dan Pengembangan Agama, 2007), h. 218 Abdul Rosyid, op. cit., h. 3 
yang menemukan fakta yang begitu mencengangkan bahwa seluruh guru mata pelajaran bahasa Arab di salah satu sekolah negeri adalah sarjana non-pendidikan bahasa Arab. Dengan kejadian ini penulis hanya mampu mengelus dada tanpa mampu bertindak lebih untuk menyikapinya.

Bahkan berdasarkan hasil wawancara dengan salah seorang siswa Madrasah Aliyah di salah satu MAS (Madrasah Aliyah Swasta) di Kota Bandung yang berinisial ASH kelas XI mengungkapkan bahwa guru mata pelajaran bahasa Arab dalam proses pembelajarannya kurang menarik, kurang tegas, menyebabkan ngantuk, mungkin kurang kompeten sehingga mayoritas siswa me-rasa kurang tertarik dengan bahasa Arab. "Saya tidak paham-paham jika diajar oleh guru bahasa Arab, bosan karena disuruh baca dan mengerjakan LKS terus" pengakuan dari ASH. Selain daripada itu, pada saat observasi awal penulis banyak menemukan hal-hal yang seharusnya tidak dilakukan oleh siswa saat proses pembelajaran berlangsung, banyak siswa yang keluar-masuk kelas untuk kepentingan yang tidak ada hubungannya dengan pembelajaran bahasa Arab, mungkin efek dari ketidak nyamanan di kelas.

Kemudian, ditambah lagi dengan adanya pengakuan sendiri dari salah satu guru bahasa Arab pada salah satu MTsN di Sumedang. Beliau merasa kurang mampu dalam mengampu pelajaran bahasa Arab, karena latar belakang pendidikan beliau adalah Pendidikan Agama Islam. "Dikarenakan tugas dari Kepala Sekolah dan tidak ada lagi yang mumpuni selain saya akhirnya dengan terpaksa saya ambil mata pelajaran bahasa Arab ini". Hal ini mungkin salah satu penyebabnya adalah latar belakang pendidikan beliau yang bukan sarjana pendidikan bahasa Arab, padahal di Bandung sendiri banyak sekali kampus-kampus yang menghasilkan sarjana pendidikan bahasa Arab, lalu pertanyaannya adalah kemanakah mereka?

Dari hasil survey awal sementara penulis menemukan data dari 41 sarjana pendidikan bahasa Arab di Universitas Pendidikan Indonesia, hanya 16 orang yang mengajar bahasa Arab itupun tidak mengajar bahasa Arab semata, namun ada yang merangkap dengan Baca Tulis al-Qur'an, Pendidikan Agama Islam, dan bahkan mata pelajaran umum seperti Ilmu Pengetahuan Alam dan Ilmu Pengetahuan Sosial. Dilihat dari data penulis tersebut dari 41 orang sarjana 16 yang mengajar bahasa Arab dan 25 orang sarjana yang memiliki profesi lain selain mengajar bahasa Arab. Kesimpulannya, 39\% linier dan 61\% tidak linier dengan profesi.

Apapun alasan mereka memilih pekerjaan lain selain yangjelas-jelas mereka memiliki sertifikat pendidik berupa akta IV pengajar bahasa Arab yang diberikan oleh Jurusan Pendidikan Bahasa Arab UPI. Namun sekarang bukanlah saatnya untuk saling menyalahkan. Penulis bertekad dengan sekuat tenaga akan memperjuangkan profesionalisme dalam mengajar bahasa Arab agar tujuan mengajar bahasa Arab tidak melenceng dan setengahsetengah, akibatnya seperti mobil dobel kabin yang mana kelihatannya seperti menjadi solusi akan tetapi tidak mampu menjadi the right solution, yang tujuannya agar keluarga dan barang bisa diangkut dengan sekaligus, namun pada akhirnya mobil tersebut tidak mampu memuat barang dengan banyak, dan keluarga pun tidak bisa semuanya masuk karena tempat duduknya hanya 3 jok untuk penumpang, hal ini menggambarkan pendidikan bahasa Arab yang masih belum matang dan masih setengah-setengah. 
Kejadian tersebut mengindikasikan bahwa masih banyaknya kesenjangan dalam pembelajaran bahasa Arab di tingkat dasar, menengah, dan atas, bahkan Perguruan Tinggi. Oleh sebab itulah penulis tertarik untuk meneliti kesenjangan ini yang berkaitan dengan kompetensi pedagogik dan kompetensi profesional guru bahasa Arab di tingkat atas atau disebut dengan Aliyah yang formalnya yaitu Madrasah Aliyah yang berlokasi di Kota Bandung. Dengan berbagai pertimbangan serta melihat pada cakupan masalah kompetensi guru terlalu luas, misalnya seperti kompetensi profesional, pedagogik, sosial, dan kepribadian sebagaimana yang telah penulis delaskan sebelumnya, maka penelitian ini dibatasi hanya akan membahas masalah kompetensi pedagogiknya dan profesionalnya saja, khususnya kompetensi pedagogik dan profesional guru bahasa Arab pada Madrasah Aliyah se-kota Bandung.

Berdasarkan pemasalahan-permasalahan yang penulis ungkapkan di atas timbulah beberapa kegelisahan yang penulis rasakan. Jika permasalahan ini tidak mulai disentuh untuk diteliti dan dicarikan solusinya, khususnya di Kota Bandung, maka permasalahan yang serupa akan kembali terulang dan terus terulang yang pada akirnya pendidikan di Kota Bandung khususnya pengajaran bidang studi bahasa Arab akan gulung tikar, hangus ditelan zaman. Oleh karena itu, berlandaskan pada permasalahan-permasalahan yang ada penulis menganggap penting dilakukan penelitian : "Tantangan Guru Bahasa Arab Madrasah Aliyah Se Kota Bandung Berkaitan dengan Kompetensi Pedagogik dan Kompetensi Profesional". Tulisan diharapkan dapat berkontribusi positif terhadap pengambil kebijakan pada pengembang satuan pendidikan bahasa Arab di Kota Bandung dan sekitarnya baik dari peningkatan mutu guru, sampai ke peningkatan kesejahteraan guru bahasa Arab.

\section{Landasan Teoritis}

Berdasarkan Undang-Undang Nomor 14 Tahun 2005 tentang Guru dan Dosen, pada pasal 10 ayat (1) menyatakan bahwa "Kompetensi guru sebagaimana dimaksud dalam Pasal 8 meliputi kompetensi pedagogik, kompetensi kepribadian, kompetensi sosial, dan kompetensi profesional yang diperoleh melalui pendidikan profesi"

Dengan kata lain, seorang guru dituntut harus menguasai keempat kompetensi guna sebagai pra syarat keguruan. Adapun kompetensi-kompetensi tersebut adalah kompetensi pedagogik, kompetensi profesional, kompetensi sosial, dan kompetensi kpribadian. Dalam studi ini kompetensi yang akan dikaji dibatasi pada kompetensi pedagogik dan profesional.

Kompetensi pedagogik yaitu kemampuan mengelola pembelajaran yang meliputipemahamanterhadappesertadidik, perancangandanpelaksanaanpembelajaran, evaluasi pembelajaran, dan pengembangan peserta didik untuk mengaktualisasikan berbagai potensi yang dimilikinya ${ }^{8}$. Secara rinci kompetensi pedagogik meliputi: (a) memahami karakteristik peserta didik dari aspek fisik, sosial, moral, kultural, emosional, dan intelektual. (b) memahami latar belakang keluarga dan masyarakat peserta didik dan kebutuhan belajar dalam konteks kebhinekaan budaya. (c) memahami gaya belajar dan kesulitan belajar peserta didik. (d) memfasilitasi pengembangan

8 Asep Supena dkk., Modul PLPG Bahasa Arab, (Malang: Konsorsium Sertifikasi, 2013), h. 138 
potensi peserta didik. (e) menguasai teori dan prinsip belajar serta pembelajaran yang mendidik. (f) mengembangkan kurikulum yang mendorong keterlibatan peserta didik dalam pembelajaran. (g) merancang pembelajaran yang mendidik. (h) melaksanakan pembelajaran yang mendidik. (i) mengevaluasi proses dan hasil pembelajaran.

Kompetensi profesional yaitu kemampuan penguasaan materi pembelajaran secara luas dan mendalam yang memungkinkannya membimbing peserta didik memenuhi standar kompetensi. ${ }^{9}$ Kompetensi ini mencakup: (a) menguasai substansi bidang studi dan metodologi keilmuannya. (b) menguasai struktur dan materikurikulumbidangstudi.(c)menguasai dan memanfaatkan teknologi informasi dan komunikasi dalam pembelajaran. (d) mengorganisasikan materi kurikulum bidang studi. (e) meningkatkan kualitas pembelajaran melalui penelitian tindakan kelas.

Jadi, seorang guru merupakan ujung tombak dalam proses pendidikan. ${ }^{10}$ Oleh karena itu, Usman menegaskan bahwa peranan dan kompetensi guru memang sangat penting dalam keberhasilan penyelenggaraan program pendidikan, dan sebagian besar ditentukan oleh peranan dan kompetensi guru tersebut. Namun demikian, tanggapan orang akan beragam mengenai seberapa besar faktor peranan dan kompetensi guru bagi keberhasilan pelaksanaan pendidikan dibandingkan faktor lainnya, seperti faktor siswa (minat, kepribadian dan kemampuan), sarana prasarana belajar, kebijakan pemerintah, lingkungan serta sistem pendidikan itu sendiri ${ }^{11}$.

\footnotetext{
$9 \quad$ Ibid., h. 139

10 Abdul Rosyid, op.cit., h. 4

11 Moh. Uzer Usman, Menjadi Guru Profesional, (Bandung: PT. Remaja Rosda Karya, 1992), h. 7
}

\section{Metodologi}

Penelitian inimenggunakan pendekatan deskriptif kualitatif naturalistik tanpa treatment yang mengungkapkan keadaan lapangan sesungguhnya salah satunya menggunakan teknik survey dengan kuesioner, angket, wawancara, dokumentasi, dan observasilangsung oleh peneliti. Karena menurut Bogdan dan Taylor, metodologi kualitatif, yaitu prosedur penelitian yang menghasilkan data deskriptif berupa kata-kata tertulis atau lisan dari orangorang dan perilaku yang dapat diamati. Penelitian kualitatif diarahkan pada latar dan individu secara holistik (utuh), tidak boleh mengisolasi individu atau organisasi ke dalam variabel atau hipotesis, ia harus dipandang sebagai bagian dari suatu keutuhan. ${ }^{12}$ Kemudian menurut Kirk dan Miller, kualitatif merupakan tradisi tertentu dalam ilmu sosial yang secara fundamental bergantung pada pengamatan manusia dalam kawasannya sendiri dan berhubungan dengan orang-orang tersebut dalam bahasanya dan peristilahannya ${ }^{13}$.

Penelitian deskriptif kualitatif ini digunakan untuk mencari fakta dengan interpretasi yang tepat dan tujuannya adalah untuk mencari deskripsi dan gambaran yang sistematis dan akurat mengenai faktor-faktor, sifat-sifat serta hubungan antara fenomena yang diselidiki. Adapun pada praktik lapangannya penelitian ini menggunakan teknik survey. Yang mana teknik survei ini digunakan untuk mengukur gejala-gejala yang ada tanpa menyelidiki kenapa gejala-gejala tersebut ada, tidak perlu diperhitungakan hubungan antara

12 R. Bogdan dan Taylor, Introducing to Qualitative Methods: Phenomenological, (NewYork : A Wlley Interscience Publication, 1975), h. 5

13 Kirk J. Kirk \& M.L. Miller, (1986). Reliability and Validity in Qualitative Research, (Beverly Hills: Sage Publications, Inc., 1986), h. 9 
variabel-variabel, lebih menggunakan data yang ada untuk pemecahan masalah dari pada pengujian hipotesis ${ }^{14}$.

Penelitian ini dilakukan pada Madrasah Aliyah sekota Bandung yang terletak di Propinsi Jawa Barat. Madrasah Aliyah di Kota Bandung berjumlah 26 Madrasah yang terdiri dari 2 Madrasah Negeri dan 24 Madrasah Swasta yang tersebar di 13 kecamatan di Kota Bandung.

Populasi dalam penelitian ini adalah seluruh guru bahasa Arab yang mengajar di Madrasah Aliyah sekota Bandung baik Madrasah Aliyah Negeri maupun Madrasah Aliyah Swasta. Berikut penulis tampilkan daftar guru bahasa Arab Madrasah Aliyah berikut jumlah sekolahnya di kota Bandung:

Tabel 1.1 Data MA di Kota Bandung

\begin{tabular}{|c|c|c|c|}
\hline No. & Sekolah & $\begin{array}{c}\text { Jumlah } \\
\text { Sekolah }\end{array}$ & $\begin{array}{c}\text { Jumlah } \\
\text { Guru }\end{array}$ \\
\hline 1. & MA Negeri & 2 & 7 \\
\hline 2. & MA Swasta & 24 & 37 \\
\hline \multicolumn{2}{|c|}{ JUMLAH } & 26 & 44 \\
\hline
\end{tabular}

Dalam penelitianini sampelyang diambil adalah keseluruhan dari populasi maka bisa disebut dengan penelitian populasi. Karena menurut Arikunto apabila subjek kurang dari 100, lebih baik diambil semua sehingga penelitiannya penelitian populasi atau total sampling ${ }^{15}$.

Pengumpulan data yang digunakan dalam penelitian ini adalah dengan cara studi dokumentasi, observasi lapangan, wawancara, angket, dan kuesioner.

Teknik analisis data yang digunakan dalam penelitian kualitatif naturalistik ini ada tiga langkah yaitu: (1) reduksi data, (2) display data, (3) kesimpulan dan verifikasi ${ }^{16}$.

14 Husein Umar, Metode Riset Bisnis, (Jakarta: PT. Gramedia Pustaka Utama, 2002), h. 88

15 Lihat Suharsimi Arikunto, Prosedur Penelitian, Suatu Pendekatan Praktik. (Jakarta: PT Rineka Cipta, 2002), h. 112

16 Ibid., h. 115
Agar lebih jelasnya akan penulis rincikan sebagai berikut:

\section{Hasil Penelitian dan Pembahasan}

1. Kompetensi pedagogik guru bahasa Arab pada Madrasah Aliyah se-Kota Bandung.

Melihat hasil penelitian yang telah penulis laksanakan pada aspek kompetensi pedagogikguru bahasa Arab Madrasah Aliyah kota Bandung, beragam pengakuan yang mereka jawab melalui kuesioner, angket maupun wawancara. Hasil penelitian menunjukan nilai pedagogik guru bahasa Arab Madrasah Aliyah kota Bandung sebesar 64.4 yang mana nilai ini mempunyai bobot $\mathrm{C}$ atau berarti cukup.

Pada proses penilaiannya penulis menyuguhkan 7 indikator ketercapaian yang penulis ambil dari pedoman PK guru terbitan Kemendiknas tahun 2010 yaitu: a). menguasai karakteristik peserta didik, b). menguasasi teori belajar dan prinsip-prinsip pembelajaran yang mendidik, c). pengembangan kurikulum, d). kegiatan pembelajaran yang mendidik, e). pengembangan potensi peserta didik, f). komunikasi dengan peserta didik, g). penilaian dan evaluasi.

Dengan menggunakan ketujuh indikator ini penulis dapat meneliti ketercapaian kompetensi pedagogik melalui pertanyaan-petanyaan kuesioner yang telah penulis ungkapkan di bagian sebelumnya.

Dengan adanya proses uji kompetensi, membuktikan bahwa kompetensi pedagogik guru bahasa Arab sangat baik dibuktikan dari hasil uji kuesioner mayoritas yang menjawab A sebanyak 30\%. Namun hasil tersebut 
jangan langsung diakui seratus persen, tetapi harus ditriangulasikan terlebih dahulu kepada kepala sekolah dan siswanya. Agar hasil dari penelitiannya tidak blur atau satu pihak saja, berikut penulis melakukan triangulasi data terhadap kepala sekolah, apakah Kepala Sekolah sebagai atasannya mengakui predikat A atau sangat baik yang diperoleh guru bahasa Arab Madrasah Aliyah kota Bandung. Dan apakah siswanya mengakui predikat A atau sangat baik yang diperoleh guru bahasa Arab Madrasah Aliyah kota Bandung.

Berdasarkan hasil triangulasi terlihat pengakuan kepala sekolah berbeda dengan hasil uji kuesioner guru dalam pembahasan sebelumnya. Pada hasil triangulasi dapat disimpulkan bahwa kompetensi pedagogik guru bahasa Arab menurut pandangan para kepala sekolah adalah mendapat predikat $\mathrm{C}$ atau cukup dengan total responden sebanyak 32\%. Dan berdasarkan hasil triangulasi terlihat pengakuan siswa berbeda dengan hasil uji kuesioner guru dalam pembahasan sebelumnya. Pada hasil triangulasi dapat disimpulkan bahwa kompetensi pedagogik guru bahasa Arab menurut pandangan para siswa adalah mendapat predikat $\mathrm{C}$ atau cukup dengan total responden sebanyak $28 \%$.

Dengan hasil triangulasi tersebut penulis mendapatkan hasil final dengan memadukan hasil uji kuesioner guru bahasa Arab dengan pengakuan para Kepala Sekolah dan para Siswanya.

Dengan hasil triangulasi data di atas penulis berkesimpulan bahwa kompetensi pedagogikguru bahasa Arab Madrasah Aliyah kota Bandung adalah C atau cukup dengan total reponden $28 \%$.
Agar lebih tervisualisasi berikut penulis gambarkan:

\section{Gambar 1.1}
Gambaran Kompetensi Pedagogik Guru
Bahasa Arab

Madrasah Aliyah se-kota Bandung

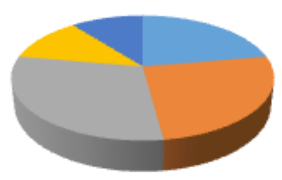

A Baik Sekali : 21\%

B Baik : $24 \%$

c Cukup : $28 \%$

\section{Kompetensi profesional guru bahasa Arab pada Madrasah Aliyah se-Kota Bandung.}

Melihat hasil penelitian yang telah penulis laksanakan pada aspek kompetensi profesional guru bahasa Arab Madrasah Aliyah kota Bandung, beragam pengakuan yang mereka jawab melalui kuesioner, angket maupun wawancara. Hasil penelitian menunjukan nilai profesional guru bahasa Arab Madrasah Aliyah kota Bandung sebesar 63.0 yang mana nilai ini mempunyai bobot $\mathrm{C}$ atau berarti cukup.

Pada proses penilaiannya penulis menyuguhkan 2 indikator ketercapaian yang penulis ambil dari pedoman PK guru terbitan Kemendiknas tahun 2010 yaitu:

a). Penguasaan materi, struktur, konsep, dan pola pikir keilmuan yang mendukung mata pelajaran bahasa Arab.

b). Mengembangkan keprofesionalan melalui tindakan yang reflektif.

Dengan menggunakan kedua indikator ini penulis dapat meneliti ketercapaian kompetensi pedagogik melalui pertanyaan-pertanyaan kuesioner yang telah penulis ungkapkan di 
bagian sebelumnya.

Proses uji kompetensi terbukti bahwa kompetensi profesional guru bahasa Arab berpredikat baik dibuktikan dari hasil uji kuesioner mayoritas responden menjawab B sebanyak 35\%. Hasil tersebut kemudian ditriangulasikan terlebih dahulu kepada kepala sekolah dan siswanya. Agar hasil dari penelitiannya tidak blur atau satu pihak saja, berikut penulis melakukan triangulasi data terhadap kepala sekolah, apakah Kepala Sekolah sebagai atasannya mengakui predikat B atau baik yang diperoleh guru bahasa Arab Madrasah Aliyah kota Bandung. Dan apakah siswanya mengakui predikat $\mathrm{B}$ atau baik yang diperoleh guru bahasa Arab Madrasah Aliyah kota Bandung.

Berdasarkan triangulasi data terlihat pengakuan kepala sekolah berbeda dengan hasil uji kuesioner guru dalam pembahasan sebelumnya. Pada matrik di atas dapat disimpulkan bahwa kompetensi profesional guru bahasa Arab menurut pandangan para kepala sekolah mendapat predikat $\mathrm{C}$ atau cukup dengan total responden sebanyak 34\%.

Berdasarkan triangulasi data terlihat pengakuan siswa sama dengan hasil uji kuesioner guru dalam pembahasan sebelumnya. Pada matrik di atas dapat disimpulkan bahwa kompetensi profesional guru bahasa Arab menurut pandangan para siswa adalah mendapat predikat $\mathrm{B}$ atau baik dengan total responden sebanyak $24 \%$.

Dengan hasil triangulasi tersebut penulis mendapatkan hasil final dengan memadukan hasil uji kuesioner guru bahasa Arab dengan pengakuan para Kepala Sekolah dan para Siswanya. Dengan hasil triangulasi data di atas penulis mengambil kesimpulan bahwa kompetensi profesional guru bahasa Arab Madrasah Aliyah kota Bandung adalah B atau baik dengan mayoritas reponden 29\%. Supaya lebih tervisualisasi penulis sajikan gambar di bawah ini:

\section{Gambar 1.2}

\section{Gambaran Kompetensi Profesional Guru Bahasa Arab \\ Madrasah Aliyah se-kota Bandung}

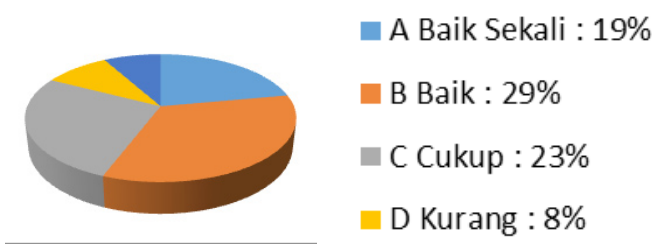

Selain tingkat ketercapaian di atas, pada aspek kompetensi profesional ini juga penulis juga menyoroti latar belakang pendidikan guru bahasa Arab Madrasah Aliyah se-kota Bandung. Adapun latar belakang ini dilihat dari pendidikan terakhir dan pendidikan pesantren guru bahasa Arab tersebut. Terdapat 13 Perguruan Tinggi, 9 bidang ilmu, dan 21 Jurusan yang melatar belakangi pendidikan guru bahasa Arab Madrasah Aliyah kota Bandung. Berikut penulis tampilkan data latar belakang pendidikan guru bahasa Arab Madrasah Aliyah kota Bandung: 
Tabel 1.2 Latar Belakang Perguruan Tinggi

\section{Guru Bahasa Arab Madrasah Aliyah}

Kota Bandung

\begin{tabular}{|c|l|c|c|}
\hline No & $\begin{array}{c}\text { Perguruan } \\
\text { Tinggi }\end{array}$ & $\begin{array}{c}\text { Jumlah } \\
\text { Guru }\end{array}$ & $\begin{array}{c}\text { Dalam } \\
\text { Persen } \\
\mathbf{( \% )}\end{array}$ \\
\hline 1 & LIPIA Jakarta & 3 & $7 \%$ \\
\hline 2 & STAI Al Falah & 1 & $2 \%$ \\
\hline 3 & $\begin{array}{l}\text { STAI Baitu } \\
\text { Arqom }\end{array}$ & 1 & $2 \%$ \\
\hline 4 & STAI Siliwangi & 1 & $2 \%$ \\
\hline 5 & STAI YAMISA & 2 & $5 \%$ \\
\hline 6 & STAIM & 1 & $2 \%$ \\
\hline 7 & STIMA Jakarta & 1 & $2 \%$ \\
\hline 8 & UIN Jakarta & 1 & $2 \%$ \\
\hline 9 & UIN SGD & $\mathbf{1 5}$ & $\mathbf{3 4 \%}$ \\
\hline 10 & UNINUS & 6 & $14 \%$ \\
\hline 11 & UNISBA & 1 & $2 \%$ \\
\hline 12 & UNPAD & 2 & $5 \%$ \\
\hline 13 & UPI Bandung & 6 & $14 \%$ \\
\hline 14 & unidentified & 3 & $7 \%$ \\
\hline & Total & 44 & \\
\hline
\end{tabular}

Tabel 1.3 Latar Belakang Bidang Ilmu

\section{Guru Bahasa Arab Madrasah Aliyah} Kota Bandung

\begin{tabular}{|c|l|c|c|}
\hline No & Bidang Ilmu & $\begin{array}{c}\text { Jumlah } \\
\text { Guru }\end{array}$ & $\begin{array}{c}\text { Dalam } \\
\text { Persen } \\
\mathbf{( \% )}\end{array}$ \\
\hline 1 & $\begin{array}{l}\text { BA (konsentrasi } \\
\text { dari PAI) }\end{array}$ & 4 & $9 \%$ \\
\hline 2 & $\begin{array}{l}\text { Menejemen } \\
\text { Pendidikan }\end{array}$ & 1 & $2 \%$ \\
\hline 3 & PAI & 9 & $20 \%$ \\
\hline $\mathbf{4}$ & PBA & $\mathbf{1 9}$ & $\mathbf{4 3 \%}$ \\
\hline 5 & Sastra Arab & 3 & $7 \%$ \\
\hline 6 & Sospol & 1 & $2 \%$ \\
\hline 7 & Syari'ah & 3 & $7 \%$ \\
\hline 8 & Tafsir Hadits & 1 & $2 \%$ \\
\hline 9 & Tekpen & 1 & $2 \%$ \\
\hline 10 & unidentified & 2 & $5 \%$ \\
\hline & Total & 44 & \\
\hline
\end{tabular}

Tabel 1.4 Latar Belakang Jurusan Guru Bahasa Arab Madrasah Aliyah Kota Bandung

\begin{tabular}{|c|c|c|c|}
\hline No & Jurusan & $\begin{array}{l}\text { Jumlah } \\
\text { Guru }\end{array}$ & $\begin{array}{c}\text { Dalam } \\
\text { Persen } \\
(\%)\end{array}$ \\
\hline 1 & BA UIN Jakarta & 1 & $2 \%$ \\
\hline 2 & $\begin{array}{l}\text { BA UIN SGD } \\
\text { Bandung }\end{array}$ & 2 & $5 \%$ \\
\hline 3 & $\begin{array}{l}\text { Menejemen } \\
\text { Pendidikan STIMA } \\
\text { Jakarta }\end{array}$ & 1 & $2 \%$ \\
\hline 4 & PAI STAI Al Falah & 1 & $2 \%$ \\
\hline 5 & $\begin{array}{l}\text { PAI STAI Baitu } \\
\text { Arqom }\end{array}$ & 1 & $2 \%$ \\
\hline 6 & PAI STAI Siliwangi & 1 & $2 \%$ \\
\hline 7 & PAI STAI YAMISA & 2 & $5 \%$ \\
\hline 8 & PAI STAIM & 1 & $2 \%$ \\
\hline 9 & PAI UIN SGD & 2 & $5 \%$ \\
\hline 10 & PAI UNISBA & 1 & $2 \%$ \\
\hline 11 & PBA LIPIA Jakarta & 1 & $2 \%$ \\
\hline 12 & PBA UIN SGD & 7 & $16 \%$ \\
\hline 13 & PBA UNINUS & 6 & $14 \%$ \\
\hline 14 & PBA UPI Bandung & 5 & $11 \%$ \\
\hline 15 & $\begin{array}{l}\text { Sastra Arab UIN } \\
\text { SGD }\end{array}$ & 2 & $5 \%$ \\
\hline 16 & $\begin{array}{l}\text { Sastra Arab } \\
\text { UNPAD }\end{array}$ & 1 & $2 \%$ \\
\hline 17 & Sospol UNPAD & 1 & $2 \%$ \\
\hline 18 & $\begin{array}{l}\text { Syari'ah LIPIA } \\
\text { Jakarata }\end{array}$ & 2 & $5 \%$ \\
\hline 19 & Syari'ah UIN SGD & 1 & $2 \%$ \\
\hline 20 & $\begin{array}{l}\text { Tafsir Hadits UIN } \\
\text { SGD }\end{array}$ & 1 & $2 \%$ \\
\hline 21 & $\begin{array}{l}\text { Tekpen UPI } \\
\text { Bandung }\end{array}$ & 1 & $2 \%$ \\
\hline 22 & unidentified & 3 & $7 \%$ \\
\hline & Total & 44 & \\
\hline
\end{tabular}

Dari data yang telah dipetakan diatas akhirnya penulis mempunyai gambaran tingkat profesionalitas guru bahasa Arab Madrasah Aliyah kota Bandung. Terdapat 43\% guru yang berlatar belakang linier dengan profesinya dan $57 \%$ guru yang berlatar belakang tidak linier dengan profesinya. Tentu saja ini menjadi sebuah bukti yang tidak bisa dibantah lagi bahwa mayoritas guru bahasa Arab di Madrasah Aliyah kota Bandung kurang memperhatikan 
linieritas latar belakang pendidikan mereka. Jika penulis mengambil kesimpulan dilihat dari keseluruhan, penulis menyimpulkan guru bahasa Arab di Madrasah Aliyah se-kota Bandung Kurang Profesional. Lebih jelasnya, perhatikan tabel dan gambar di bawah ini:

Tabel 1.5 Linieritas Latar Belakang Pendidikan

Guru Bahasa Arab Madrasah Aliyah Kota Bandung

\begin{tabular}{|l|l|c|c|}
\hline No & Linieritas & $\begin{array}{c}\text { Jumlah } \\
\text { Guru }\end{array}$ & $\begin{array}{c}\text { Dalam } \\
\text { Persen } \\
\text { (\%) }\end{array}$ \\
\hline 1 & Linier & 19 & $43 \%$ \\
\hline 2 & Tidak Linier & 25 & $57 \%$ \\
\hline \multicolumn{2}{|c|}{ Total } & 44 & \\
\hline
\end{tabular}

\section{Gambar 1.3}

Gambaran Linieritas Latar Belakang Pendidikan GBA MA Kota Bandung

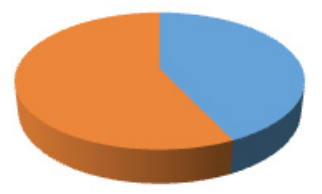

Linier : 43\%

- Tidak Linier : $57 \%$

Walaupun data menyebutkan mayoritas guru bahasa Arab tidak linier dengan profesinya, hendaknya hal ini didukung dengan pendidikan pesantren. Merupakankabaryangmenggembirakan sebanyak 31 dari 44 atau sebanyak 70\% nya guru bahasa Arab Madrasah Aliyah di kota Bandung pernah mengenyam pendidikan pesantren. Untuk lebih tervisualisasi berikut penulis paparkan melalui tabel dan gambar mengenai latar belakan pendidikan pesantren guru bahasa Arab Madrasah Aliyah di kota Bandung.
Tabel 1.6 Pendidikan Pesantren Guru Bahasa Arab Madrasah Aliyah Kota Bandung

\begin{tabular}{|l|l|c|c|}
\hline No & $\begin{array}{c}\text { Pendidikan } \\
\text { Pesantren }\end{array}$ & $\begin{array}{c}\text { Jumlah } \\
\text { Guru }\end{array}$ & $\begin{array}{c}\text { Dalam } \\
\text { Persen } \\
\text { (\%) }\end{array}$ \\
\hline 1 & Pesantren & 31 & $70 \%$ \\
\hline 2 & Tidak & 13 & $30 \%$ \\
\hline \multicolumn{2}{|c|}{ Total } & 44 & \\
\hline
\end{tabular}

Gambar 1.4

Gambaran Latar Belakang Pendidikan Pesantren GBA MA Kota Bandung

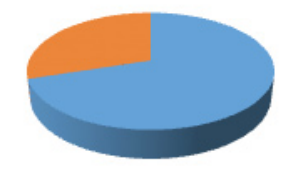

- Pesantren : 70\%

- Tidak Pesantren : 30\%

\section{Upaya peningkatan kompetensi} yang dilakukan oleh GBA MA se Kota Bandung

Berberapa data yang didapatkan dari hasil angket dan wawancara. Berikut penulis paparkan simpulan secara menyeluruh upaya-upaya guru bahasa Arab MA dalam meningkatkan kompetensinya.

\section{Tabel 1.7}

Upaya Guru Bahasa Arab MA Kota Bandung dalam meningkatkan kompetensi pedagogik dan profesional

\begin{tabular}{|c|l|}
\hline No & $\begin{array}{l}\text { Bentuk Upaya-upaya GBA dalam } \\
\text { meningkatkan Kompetensinya }\end{array}$ \\
\hline 1 & $\begin{array}{l}\text { Mengikuti Pelatihan-Pelatihan, Diklat } \\
\text { atau Up Grading guru bahasa Arab }\end{array}$ \\
\hline 2 & Mengikuti Seminar-Seminar \\
\hline 3 & $\begin{array}{l}\text { Studi Bandung ke Madrasah atau } \\
\text { Sekolah lain }\end{array}$ \\
\hline 4 & $\begin{array}{l}\text { Menggali lebih dalam bahasa Arab } \\
\text { dengan mengikuti kajian-kajian khusus/ } \\
\text { umum }\end{array}$ \\
\hline 5 & $\begin{array}{l}\text { Melanjutkan pendidikan ke jenjang yang } \\
\text { lebih tinggi yang linier dengan profesi }\end{array}$ \\
\hline 6 & $\begin{array}{l}\text { Mencari informasi seminar-seminar } \\
\text { atau pelatihan-pelatihan yang berkaitan } \\
\text { dengan pendidikan bahasa Arab }\end{array}$ \\
\hline
\end{tabular}




\begin{tabular}{|c|c|}
\hline 7 & $\begin{array}{l}\text { Sharing atau diskusi dengan guru } \\
\text { bahasa Arab di lingkungan KKM } \\
\text { (Kelompok Kerja Madrasah) }\end{array}$ \\
\hline 8 & $\begin{array}{l}\text { Mencari referensi-referensi yang } \\
\text { berkaitan dengan pengajaran bahasa } \\
\text { Arab }\end{array}$ \\
\hline 9 & $\begin{array}{l}\text { Melakukan uji coba metode-metode } \\
\text { baru guna meningkatkan kualitas } \\
\text { pembelajaran bahasa Arab }\end{array}$ \\
\hline 10 & $\begin{array}{l}\text { Memperbanyak hafalan percakapan dan } \\
\text { kaidah-kaidah kebahasaaraban }\end{array}$ \\
\hline 11 & $\begin{array}{l}\text { Memperhatikan ketepatan materi yang } \\
\text { diajarkan di kelas dengan RPP, Silabus, } \\
\text { dan Kurikulum }\end{array}$ \\
\hline 12 & $\begin{array}{l}\text { Memasang parabola yang ada siaran } \\
\text { timur tengah }\end{array}$ \\
\hline 13 & $\begin{array}{l}\text { Selalu mengadakan evaluasi hasil } \\
\text { belajar dan proses pembelajaran } \\
\text { sehingga guru mampu menentukan } \\
\text { materi dan metode pengajaran yang } \\
\text { tepat untuk siswa }\end{array}$ \\
\hline 14 & $\begin{array}{l}\text { Melakukan penelitian yang berkaitan } \\
\text { dengan teknik pengajaran bahasa Arab } \\
\text { seperti PTK atau sejenisnya }\end{array}$ \\
\hline 15 & $\begin{array}{l}\text { Menyusun bahan ajar yang sesuai } \\
\text { dengan kebutuhan siswa seperti diktat, } \\
\text { modul atau sejenisnya. }\end{array}$ \\
\hline 16 & $\begin{array}{l}\text { Selalu mempersiapkan dengan matang } \\
\text { mengenai materi-materi yang akan } \\
\text { disajikan setiap harinya melalui RPP } \\
\text { dan sejenisnya }\end{array}$ \\
\hline 17 & $\begin{array}{l}\text { Mengotimalkan MGMP bahasa Arab di } \\
\text { tingkat sekolah }\end{array}$ \\
\hline 18 & $\begin{array}{l}\text { Membuat pemetaan materi bahasa } \\
\text { Arab sesuai jenjang pendidikan agar } \\
\text { terpetakan pencapaian kompetensinya }\end{array}$ \\
\hline 19 & $\begin{array}{l}\text { Selalu berusaha untuk untuk menguasai } \\
\text { karakteristik siswa dari aspek fisik, } \\
\text { moral, sosial, kultural, emosional, dan } \\
\text { intelektualnya }\end{array}$ \\
\hline 20 & $\begin{array}{l}\text { Menyelenggarakan pembelajaran yang } \\
\text { mendidik siswa }\end{array}$ \\
\hline 21 & $\begin{array}{l}\text { Mengadakan les/pelajaran tambahan } \\
\text { berkenaan dengan mata pelajaran } \\
\text { bahasa Arab }\end{array}$ \\
\hline 22 & $\begin{array}{l}\text { Mengikutsertakan anak didiknya dalam } \\
\text { acara-acara perlombaan bahasa Arab }\end{array}$ \\
\hline 23 & $\begin{array}{l}\text { Membuat kamus bahasa Arab yang } \\
\text { sesuai dengan jenjang pendidikan siswa }\end{array}$ \\
\hline 24 & $\begin{array}{l}\text { Menciptakan pembelajaran yang } \\
\text { menyenangkan dan tidak menjenuhkan } \\
\text { siswa }\end{array}$ \\
\hline 25 & $\begin{array}{l}\text { Melakukan diskusi dengan siswa } \\
\text { mengenai materi dan teknik } \\
\text { mengajarnya }\end{array}$ \\
\hline
\end{tabular}

\begin{tabular}{|c|l|}
\hline 26 & $\begin{array}{l}\text { Selalu memotivasi siswa untuk lebih } \\
\text { giat lagi menekuni bahasa Arab }\end{array}$ \\
\hline 27 & $\begin{array}{l}\text { Menggunakan berbagai media untuk } \\
\text { mengajar seperti media cetak, film/ } \\
\text { tayangan video berbahasa Arab, } \\
\text { website, majalah/koran berbahasa } \\
\text { Arab, dll }\end{array}$ \\
\hline 28 & $\begin{array}{l}\text { Mengadakan muhadloroh mingguan } \\
\text { (pidato bahasa Arab) }\end{array}$ \\
\hline
\end{tabular}

4. Harapan-harapan responden terhadap pemenuhan kompetensi pedagogik dan profesional yang sebaiknya dilakukan oleh UPI

Menurut hasil pengumpulan data melalui angket dan wawancara banyak sekali harapan-harapan yang reponden utarakan kepada penulis. Namun dari harapan-harapan ini ada yang berbeda dan ada juga yang mempunyai maksud yang sama. Berikut penulis rangkum harapan-harapan responden terhadap pemenuhan kompetensi pedagogik dan profesional guru bahasa Arab yang sebaiknya dilakukan oleh UPI.

Tabel 1.8

\section{Harapan-harapan Responden}

\begin{tabular}{|c|l|}
\hline No & Harapan-Harapan Responden \\
\hline 1 & $\begin{array}{l}\text { Mengadakan seminar, pelatihan, } \\
\text { diklat, workshop, upgrading minimal } \\
\text { dua kali dalam satu semester (tidak } \\
\text { hanya mendengarkan materi saja } \\
\text { namun peserta juga ikut langsung } \\
\text { mempraktikannya) }\end{array}$ \\
\hline 2 & $\begin{array}{l}\text { Merancang dan membuat bahan ajar, } \\
\text { media, dan metode pembelajaran } \\
\text { untuk guru-guru bahasa Arab yang } \\
\text { sesuai dengan kurikulum 2013 dan } \\
\text { materi yang pas untuk peserta didik } \\
\text { di NKRI }\end{array}$ \\
\hline 3 & $\begin{array}{l}\text { Mengadakan kerjasama (kunjungan) } \\
\text { yang terjadwal ke Madrasah dalam } \\
\text { rangka membimbing guru-guru } \\
\text { bahasa Arab }\end{array}$ \\
\hline
\end{tabular}




\begin{tabular}{|c|c|}
\hline 4 & $\begin{array}{l}\text { Memperbaharui ketercapaian } \\
\text { kompetensi pedagogik dan profesional } \\
\text { guru bahasa Arab sehingga sesuai } \\
\text { dengan kurikulum } 2013\end{array}$ \\
\hline 5 & $\begin{array}{l}\text { Memfasilitasi beasiswa untuk guru } \\
\text { bahasa Arab agar dapat melanjutkan } \\
\text { ke jenjang yang lebih tinggi }\end{array}$ \\
\hline 6 & $\begin{array}{l}\text { Agar lebih memperhatikan lulusannya } \\
\text { dengan cara selalu mengadakan } \\
\text { kordinasi (arahan) bagi alumni } \\
\text { pendidikan Bahasa Arab UPI }\end{array}$ \\
\hline 7 & $\begin{array}{l}\text { Memberi contoh mengajar yang baik } \\
\text { bagi guru-guru bahasa Arab seperti } \\
\text { micro teaching atau sejenisnya dengan } \\
\text { menggunakan sistem training center } \\
\text { yang dikelola secara profesional }\end{array}$ \\
\hline 8 & $\begin{array}{l}\text { UPI harusnya menciptakan dan } \\
\text { menyebarkan media (CD, atau } \\
\text { sejenisnya) yang sesuai dengan } \\
\text { kurikulum terbaru, karena bahan ajar } \\
\text { dari penerbit luar atau dari Kemenag } \\
\text { masih banyak kekurangannya }\end{array}$ \\
\hline 9 & $\begin{array}{l}\text { Senantiasa memberikan informasi } \\
\text { jurnal-jurnal pendidikan bahasa Arab } \\
\text { terbaru }\end{array}$ \\
\hline 10 & $\begin{array}{l}\text { Mengadakan pelayanan satu pintu } \\
\text { untuk tempat konsultasi para guru } \\
\text { bahasa Arab baik yang berkenaan } \\
\text { dengan materi ataupun dengan } \\
\text { keprofesiannya. Berikut menyediakan } \\
\text { websitenya yang mudah untuk diakses }\end{array}$ \\
\hline 11 & $\begin{array}{l}\text { Membuat jaringan yang lebih luas/ } \\
\text { global untuk jaringan internasional }\end{array}$ \\
\hline 12 & $\begin{array}{l}\text { Sering mengadakan perlombaan } \\
\text { bahasa Arab untuk tingkat Madrasah }\end{array}$ \\
\hline
\end{tabular}

\section{Simpulan}

Berangkat dari teori ketercapaian kompetensi pedagogik dan profesional yang berpedoman pada buku pedoman Profesi Keguruan guru terbitan Kemendiknas tahun 2010 dengan ketujuh indikatornya menyebutkan bahwa kompetensi pedagogik guru bahasa Arab Madrasah
Aliyah kota Bandung masih perlu untuk ditingkatkan, karena tingkat ketercapainnya masih mendapatkan nilai $\mathrm{C}$ atau cukup. Peningkatan yang dilakukan bisa dengan cara menindaklanjuti dan mengaplikasikan atau mempraktikkan harapan-harapan para responden.

Begitupun dengan kompetensi profesional yang telah dicapai oleh guru bahasa Arab Madrasah Aliyah kota Bandung juga masih perlu untuk ditingkatkan, walaupun tingkat ketercapaiannya sudah mendapatkan nilai B atau baik akan tetapi lebih baik lagi jika mendapatkan nilai A atau sangat baik. Karena dilihat dari linieritas latar belakang pendidikannya yang mayoritas tidak sesuai dengan profesi yang digelutinya, walaupun tertolong dengan pendidikan pesantren yang telah mereka kenyam.

Melihat antusiasme guru bahasa Arab dalam upaya meningkatkan kom-petensinya tampaknya harus dibarengi dengan fasilitas yang disediakan oleh UPI sebagai institusi yang menyelenggarakan pendidikan keguruan. Karena jika tidak difasilitasi oleh UPI, mereka (guru-guru bahasa Arab) tidak akan tahu arah metode atau materi yang baik dan terbaru di saat ini. Hal ini terlihat dari harapan-harapan yang sangat besar yang mana mereka berharap agar UPI peduli dan memikirkannya tidak hanya asik di dunia perguruan tinggi saja, tetapi sebaiknya masuk ke sendi-sendi kehidupan Madrasah dan mengadakan kerjasama yang berkesinambungan. Karena bagaimanapun juga Madrasah adalah cikal bakal perguruan tinggi. Dan tidak akan ada mahasiswa di Perguruan Tinggi tanpa adanya siswa Madrasah atau setingkatnya.

Di akhir tulisan ini dapat disimpulkan bahwa tantangan guru bahasa Arab di Era Modren adalah sebagai berikut: 
1. Menguasai empat kompetensi keguruan yaitu: pedagogik, profesional, kepribadian, dan sosial.

2. Memahami minat dan bakat peserta didik dan yang mempengaruhi keduanya melalui faktor internal dan eksternal.

3. Menguasai teknologi pembelajaran dengan wujud menciptakan bahan dan media ajar bahasa Arab yang sesuai dengan perkembangan teknologi saat ini.

4. Berperan aktif dalam organisasi keguruan atau organisasi profesi, seperti aktif menjadi anggota atau pengurus Ittihhâd Mudarrisî al-Lughah al-'Arabiyyah.

5. Berperan aktif dalam berbagai perlombaan baik di tingkat lokal maupun nasional bahkan internasional

6. Membina hubungan baik dengan institusi-institusi kependidikan

7. Cerdas, tepat dan berwawasan luas

8. Selalu melakukan riset pada pembelajaran bahasa Arab guna tercapainya pembelajaran yang efektif, efisien, dan menyenangkan.

\section{Implikasi}

Memiliki guru bahasa Arab yang profesional dan memiliki kompetensi pedagogik yang baik merupakan implikasi penelitian ini. Tujuan penelitian ini tidaklah lain agar pengajaran bahasa Arab di tingkat Madrasah lebih sukses dan membanggakan. Dapat bersaing tidak hanya di kancah masyarakat nasional saja tetapi siswa madrasah harus berperan dan menunjukan taringnya di kancah internasional dengan modal kemampuan dan pengetahuan bahasa Arab yang maksimal.

Terciptanya perhatian dan kepedulian dari Kementerian yang terkait dan institusiinstitusi penyelenggara pendidikan keguruan bahasa Arab, terhadap keberlangsungan bahasa Arab di tingkat Madrasah juga merupakan implikasi dari penelitian ini. Bentuk kepedulian tersebut dapat berupa respon dari stimulus yang telah diberikan, dengan menggunakan gambaran data-data nyata di lapangan yang telah penulis petakan pada bab sebelumnya. []

\section{Daftar Rujukan}

Abdul, Rosyid. Kompetensi Pedagogik Guru Bahasa Arab Berlatar Belakang Non-Pendidikan Bahasa Arab dalam Pembelajaran Bahasa Arab di MTsN Maguwoarjo Yogyakarta. Yogyakarta: Skripsi UIN Sunan Kalijaga Yogyakarta, 2013.

al-Bukhari, Abu Abdullah Muhammad bin Ismail bin Ibrahim bin al-Mughirah bin Bardizbah al-Ju'fi. Shahih al-Bukhariy al-Juz al-Awwal, Beirut: Dar al-Kutub, tt.

Al-Fauzan. Abdurrahman bin Ibrahim. Idaat li Muallimi al-Lughah al-Arabiyah lighairi al-Natiqin biha, Riyadh: Syirkah al-Arabiyah li al-Jami', $1432 \mathrm{H}$.

Arifin, Zainal. Penerapan Kompetensi Pedagogik Dan Kompetensi Profesional di Kalangan Guru Bahasa Arab Pada Madrasah Tsanawiyah Se-Kabupaten Rembang (Studi Deskriptif Evaluatif). Tesis Pasca Sarjana Pendidikan Bahasa Arab Malang: Tidak Diterbitkan, 2011.

Arikunto, Suharsimi. Prosedur Penelitian, Suatu Pendekatan Praktek. Jakarta: PT Rineka Cipta, 2002.

Bogdan R. dan Taylor. Introducing to Qualitative Methods: Phenomenological. NewYork : A Wlley Interscience Publication, 1975.

Kirk J. \& Miller M.L. Reliability and Validity in Qualitative Research. Beverly Hills: Sage Publications, Inc., 1986. 
Permenag. RI Nomor 02 tahun 2008 tentang Standar Kompetensi Lulusan dan Standar Isi PAI dan Bahasa Arab di Madrasah.

Sauri, Sofyan, Membangun Profesionalisme Guru Berbasis Nilai Bahasa Santun, Bagi Pembinaan Kepribadian Bangsa yang Bijak. Pengukuhan Guru Besar Universitas Pendidikan Indonesia, Bandung: UPI Pres, 2006.

Sumarsih, Anwar dkk., Kompetensi Guru Madrasah. Jakarta: Balai Penelitian dan Pengembangan Agama, 2007.
Supena, Asep dkk., Modul PLPG Bahasa Arab. Malang: Konsorsium Sertifikasi, 2013

Umar, Husein, Metode Riset Bisnis, PT. Gramedia Pustaka Utama, Jakarta, 2002.

Undang-undang RI No 14 Tahun 2005 tentang Guru dan Dosen

Usman, Mohammad Uzer, Menjadi Guru Profesional. Bandung: PT. Remaja Rosda Karya, 1992. 